\title{
Phosphorus removal by a fixed-bed hybrid polymer nanocomposite biofilm reactor
}

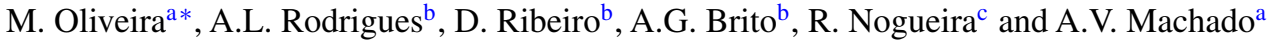 \\ ${ }^{a}$ Department of Polymers Engineering, Institute of Polymers and Composites/I3N, University of Minho, \\ Guimarães, Portugal, ${ }^{b}$ Department of Biological Engineering, Institute for Biotechnology and \\ Bioengineering, Centre of Biological Engineering, University of Minho, Braga, Portugal; ${ }^{c}$ Department of \\ Civil Engineering, Institute of Sanitary Engineering and Waste Management, University of Hannover, \\ Hannover, Germany
}

(Received 25 February 2013; final version received 15 November 2013)

\begin{abstract}
Eutrophication is one of the main challenges regarding the ecological quality of surface waters, phosphorus bioavailability being its main driver. In this context, a novel hybrid polymer nanocomposite (HPN-Pr) biofilm reactor aimed at integrated chemical phosphorus adsorption and biological removal was conceived. The assays pointed to removal of $1.2 \mathrm{mg} \mathrm{P} / \mathrm{g}$ of reactive phosphorus and $1.01 \mathrm{mg} \mathrm{P} / \mathrm{g}$ of total phosphorus under steady-state conditions. A mathematical adsorption-biological model was applied to predict reactor performance, which indicated that biological activity has a positive effect on reactor performance, increasing the amount of reactive phosphorus removed.
\end{abstract}

Keywords: eutrophication; phosphorus adsorption; hybrid nanocomposite

\section{Introduction}

The leaching of surplus fertilisers from agriculture and the discharge of phosphorus (P)-rich wastewaters are among the most significant anthropogenic pressures on river basins.[1,2] As a consequence, severe loss of ecosystem biodiversity occurs and water abstraction is at risk when toxins are released following cyanobacteria blooms.[3] The eutrophication of aquatic environments, such as lakes or rivers, has been noted since the 1950s, and the phenomenon is far from being solved, affecting 53\% of European lakes and many others around the world.[4] The European Water Framework Directive (WFD-2000/60/EC) aimed to restore water body quality by 2015, but derogations have been claimed when eutrophication is the main pressure. Currently, even when external $\mathrm{P}$ sources are eliminated, slow recuperation is observed due to the redissolution of $\mathrm{P}$ accumulated in sediments.[5,6] Furthermore, polyphosphates may also have a crucial role, since they gradually hydrolyse into phosphates. $[2,7,8]$

The search for and development of technologies for P removal started in 1950s, with the aim of reducing the amount of $\mathrm{P}$ arriving at the water surface. Nowadays, chemical precipitation is the main commercial process used to remove $\mathrm{P}$ from eutrophic mediums and wastewater. It is based on the direct application of salts like aluminium, iron or calcium, industrial byproducts and

*Corresponding author. Email: moliveira@dep.uminho.pt, avm@dep.uminho.pt 
mineral clays to the water.[3,9,10] Nevertheless, direct application of chemicals has recognised drawbacks, such as possible contamination by heavy metals, tight control of the $\mathrm{pH}$ to avoid dissolution of the precipitates, chemical overdose to guarantee the desired degree of removal due to parallel reactions and the possibility of increasing turbidity for long periods.[11-15] Moreover, most commercial products have been developed to precipitate $\mathrm{P}$ and not to recover it.

$\mathrm{P}$ recovery has become an important issue because the main source of $\mathrm{P}$ is phosphate rock, a non-renewable source like oil, which is becoming scarce and expensive.[16,17] Consumption of phosphate rock grows by $2.7 \%$ per year, increasing from $17.8 \mathrm{t}$ in 2008 to $19.8 \mathrm{t}$ in 2012.[18]

To overcome some of the disadvantages of the commercial materials, a new polymeric material was developed (HPN-Pr). According to previous results, it is stable, does not provoke any chemical contamination or change in $\mathrm{pH}$ and can be design to be introduced locally into the water body without dissolution or loss of physical shape.[19] Moreover, after water treatment, it is possible to recover the adsorbed $\mathrm{P}$, thereby contributing to the sustainability of this non-renewable nutrient, and regenerate the material to be used again.

Even though biological P-removal is a well-established process in wastewater treatment plants and in natural mediums, such as lake and rivers, there has been a considerable lack of research.[20] Therefore, the aim of this study was to assess the efficiency of a new bioreactor using HPN-Pr media for both chemical adsorption and the biological removal of $\mathrm{P}$ from natural water. The specific goals of the study were: (1) to evaluate the effect on $\mathrm{pH}$ and the efficiency for polyphosphate removal, and (2) to test the HPN-Pr bioreactor performance regarding the elimination of soluble reactive phosphorus (SRP) and total phosphorus (TP).

\section{Materials and methods}

\subsection{HPN-Pr synthesis}

HPN-Pr is a hybrid nanocomposite containing $1.4 \%$ aluminium that results from a reaction between polypropylene grafted with maleic anhydride (PP-g-MA, Polybond 3200 supplied by Crompton) and aluminium isopropoxide $\left[\mathrm{Al}(\mathrm{Pr}-\mathrm{i}-\mathrm{O})_{3}\right.$, acquired from Sigma Aldrich] using a solgel process in an extruder at $180^{\circ} \mathrm{C}$. The density of the nanocomposite was initially of $0.93 \mathrm{~g} / \mathrm{dm}^{3}$ and was increased to $1.2 \mathrm{~g} / \mathrm{dm}^{3}$ by the addition of antimony trioxide $\left(\mathrm{Sb}_{2} \mathrm{O}_{3}\right)$. The HPN-Pr was milled in pellets $3 \mathrm{~mm}$ long. A more detailed description of the synthesis process and properties of HPN-Pr can be found in the references.[21,22]

\subsection{Reactor operation I: pre-feasibility studies without biofilm}

\subsubsection{Effect of $p H$ on phosphate removal by $\mathrm{HPN}-\mathrm{Pr}$}

Experiments were done in a column $260 \mathrm{~mm}$ long and $30 \mathrm{~mm}$ in diameter filled with $50 \mathrm{~g}$ of HPN-Pr. The fixed-bed porosity, determined by the gravimetric method, was 0.4 . Synthetic water containing $200 \mu \mathrm{g} \mathrm{P} / \mathrm{L}$ was prepared with potassium dihydrogenophosphate $\left(\mathrm{KH}_{2} \mathrm{PO}_{4}\right.$, Merck), initial $\mathrm{pH}$ values of 5, 6, 7 and 8 , and was passed in upflow mode at a rate of $0.5 \mathrm{~mL} / \mathrm{min}$ over 15 days. Empty bed hydraulic retention time (the time that the water is inside the column), calculated taking into account the column volume, material porosity and flow rate, was $2.5 \mathrm{~h}$. The experiments were performed in duplicate and stopped when the equilibrium concentration in the liquid phase was reached. The $\mathrm{P}$ removal capacity $\left(\mathrm{C} / \mathrm{C}_{0}\right)$ was expressed as the ratio between the $P$ concentrations at outlet $(C)$ and inlet $\left(\mathrm{C}_{0}\right)$. 
Table 1. Characterisation of Cávado river water quality.

\begin{tabular}{lcccccc}
\hline $\mathrm{pH}$ & $\mathrm{SRP}(\mu \mathrm{g} / \mathrm{L})$ & Total P $(\mu \mathrm{g} / \mathrm{L})$ & Carbon TC $(\mathrm{mg} / \mathrm{L})$ & Carbon TOC $(\mathrm{mg} / \mathrm{L})$ & TSS $(\mathrm{mg} / \mathrm{L})$ & VSS $(\mathrm{mg} / \mathrm{L})$ \\
\hline $6.56 \pm 0.02$ & $266 \pm 1$ & $267 \pm 11$ & $232 \pm 11$ & $214 \pm 16$ & $0.60 \pm 0.03$ & $0.50 \pm 0.04$ \\
\hline
\end{tabular}

\subsection{Polyphosphate removal by $\mathrm{HPN}-\mathrm{Pr}$ at $\mathrm{pH} 6$}

A polyphosphate solution containing $100 \mu \mathrm{gP} / \mathrm{L}$ with an initial $\mathrm{pH}$ of 6 was passed upflow through the column at rate of $0.5 \mathrm{~mL} / \mathrm{min}$. The experiments were carried out in duplicate and pentasodiumtripolyphosphate $\left(\mathrm{Na}_{5} \mathrm{P}_{3} \mathrm{O}_{10} \cdot 6 \mathrm{H}_{2} \mathrm{O}\right.$, Sigma Aldrich) was used as polyphosphate source.

\subsection{Reactor operation II: start-up operation with biofilm growth}

\subsubsection{Water characterisation}

The Cávado River provided the feed water used in these experiments. The Cávado watershed is an intense agricultural region in northern Portugal where eutrophication is reported. The average water $\mathrm{pH}$ was 6.6 and the TP and SRP concentrations were 267 and $265 \mu \mathrm{g} \mathrm{P} / \mathrm{L}$, respectively. Total carbon (TC), total organic carbon (TOC), total suspended solids (TSS) and volatile suspended solids (VSS) were determined according to Standard Methods.[23] The water sample collected was stored at $4^{\circ} \mathrm{C}$ for one day before use. Table 1 presents the water quality characterisation.

\subsubsection{Column reactor set-up}

The experimental bioreactor set-up consisted of two connected acrylic columns as depicted in Figure 1 . The first column was $300 \times 50 \mathrm{~mm}$ and the second $260 \times 30 \mathrm{~mm}$ (length $\times$ diameter). Both columns were filled with $400 \mathrm{~g}$ of HPN-Pr. The operation conditions were the same as those used in the experiments described above and the total hydraulic retention time in both columns was $10.4 \mathrm{~h}$. The bioreactors were run until equilibrium state was reached, which took 50 days. Samples were taken daily during the first 30 days of operation and twice a week afterwards until the end of the 50-days experiment. The biofilm formed on the surface of the HPN-Pr was quantified as total solids (TS) and its bacterial diversity was assessed by DGGE patterns of partial 16S rRNA gene amplicons.

\subsection{Mathematical simulation}

Phosphate removal was hypothesised to occur sequentially, first by physio-chemical adsorption on the HPN-Pr support and then by biological metabolism. In order to test this hypothesis, a mathematical model was used based on the saturated soil compartment of AQUASIM.[24] The details needed for this model are presented in Table 2. The adsorption process was described using a Freundlich isotherm (Equation 1), where $S$ is the amount of $\mathrm{P}$ adsorbed $(\mathrm{g} / \mathrm{kg}), C$ is the equilibrium concentration $(\mathrm{mg} / \mathrm{L}), K_{\mathrm{f}}$ and $\alpha$ are the adsorption constants.

$$
S=K_{f} \times C^{\alpha}
$$

The biological consumption process is described by a Monod-type equation (Equation 2), where $R$ is the specific grow rate of microorganism $\left(\mathrm{h}^{-1}\right), \mu_{\max }$ is the maximum specific grow rate $\left(\mathrm{h}^{-1}\right)$, 


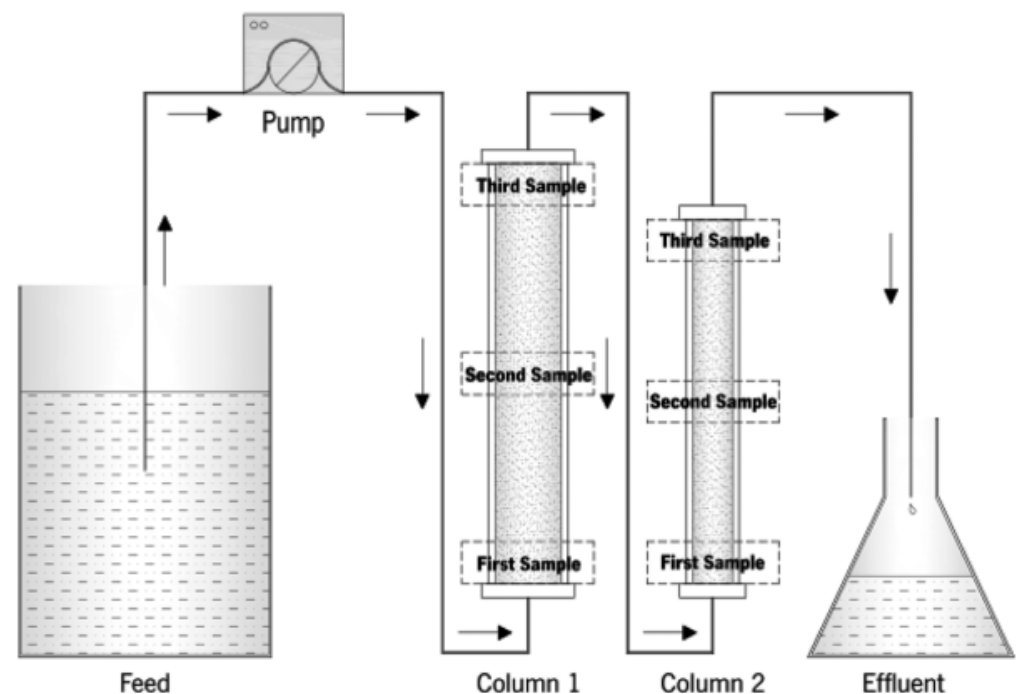

Figure 1. Scheme of the experimental set-up.

Table 2. Inputs parameters introduced into the AQUASIM model.

\begin{tabular}{|c|c|c|c|}
\hline Variable & Value & Units & Description \\
\hline \multicolumn{4}{|l|}{ Constants variables } \\
\hline $\begin{array}{l}\mathrm{A} 1 \\
\mathrm{~A} 2 \\
\mathrm{C}_{\text {in }} \\
\text { Half saturation coefficient, } K_{\mathrm{m}} \\
\text { Q }_{\text {in }} \\
\text { theta } \\
\text { rho_s } \\
\text { L1 } \\
\text { L2 }\end{array}$ & $\begin{array}{c}0.00196 \\
0.00071 \\
265 \\
55 \\
0,00003 \\
0.4 \\
1200 \\
0.3 \\
0.26\end{array}$ & $\begin{array}{c}\mathrm{m}^{2} \\
\mathrm{~m}^{2} \\
\mathrm{mg} / \mathrm{m}^{3} \\
\mu \mathrm{g} / \mathrm{L} \\
\mathrm{m}^{3} / \mathrm{h} \\
\mathrm{kg} / \mathrm{m}^{3} \\
\mathrm{~m} \\
\mathrm{~m}\end{array}$ & $\begin{array}{l}\text { Cross-sectional area of column } 1 \\
\text { Cross-sectional area of column } 2 \\
\text { Input concentration of } \mathrm{P}\end{array}$ \\
\hline \multicolumn{4}{|c|}{ Dynamic variables (State variables) } \\
\hline $\begin{array}{l}\mathrm{C} \\
\mathrm{S} \\
\mathrm{P} \_ \text {bio } \\
\text { Grid resolution }\end{array}$ & 152 & $\begin{array}{c}\mathrm{mg} / \mathrm{m}^{3} \\
\mathrm{mg} / \mathrm{kg} \\
\mathrm{mg} / \mathrm{g} \\
\text { grid points }\end{array}$ & $\begin{array}{l}\text { Concentration of } \mathrm{P} \text { in water } \\
\text { Adsorbed } \mathrm{P} \text { to hybrid polymer } \\
\text { Absorbed } \mathrm{P} \text { by microorganism }\end{array}$ \\
\hline
\end{tabular}

$K_{m}$ is the Monod constant and $C$ is the limiting substrate concentration $(\mathrm{g} / \mathrm{L})$ :

$$
R=\frac{\mu_{\max } \times C}{K_{\mathrm{m}}+C}
$$

The parameters of the Freundlich isotherm, $K$ and $n$, were calculated as $0.76 \mathrm{mg}^{1-n} / \mathrm{L}^{n} / \mathrm{g}$ and 1.79 , respectively, with $R^{2}=0.986$. A more detailed description can be found in Oliveira et al.[19] The parameters of the Monod equation were estimated through the model adjustment to experimental data. The kinetic parameters are presented in Table 3.

The cross-sectional area of columns 1 and 2 was 511 and $259 \mathrm{~cm}^{2}$ and the length was 300 and $260 \mathrm{~mm}$, respectively. 
Table 3. Kinetic data of Freundlich and Monod models.

\begin{tabular}{lcc}
\hline Parameter & Value & Units \\
\hline Adsorption constant, alpha & $0.56 \pm 0.02$ & - \\
Adsorption constant, $K_{\mathrm{F}}$ & $0.76 \pm 0.07$ & - \\
$R^{2}$, Freundlich model & 0.986 & \\
Maximum growth rate, $\mu_{\max }$ & 0.12 & $\mathrm{~h}^{-1}$ \\
Half saturation coefficient, $K_{\mathrm{m}}$ & 55 & $\mu \mathrm{g} / \mathrm{L}$ \\
\hline
\end{tabular}

\subsection{Analytical methods}

The concentrations of SRP and TP were measured as phosphate using ascorbic acid method (Method 4500P-E) according to the Standard Methods (1998).[23] Polyphosphate was quantified as total $\mathrm{P}$ in samples that had been previously digested (Method 4500P-E).[23] To quantify TS and TP in the biofilm grown on the surface of HPN-Pr particles, $\sim 1 \mathrm{~g}$ of the material was collected in each sampling port of the columns after 50 days of operation (Figure 1) and was shaken intensely in a vortex for $1 \mathrm{~min}$ to release the biofilm from the material. The TS of the biofilm suspension was measured using the gravimetric method according to the Standard Methods.[23] Total $\mathrm{P}$ was measured after digestion of the biofilm suspension as previously described.

The $\mathrm{P}$ adsorbed on the HPN-Pr was quantified after the biofilm removal step. Thus, the material was washed with $10 \mathrm{~mL} 0.5 \mathrm{M} \mathrm{H}_{2} \mathrm{SO}_{4}$ solution for $1 \mathrm{~h}$ as described in Oliveira et al. [19]. Afterwards, the solution was neutralised and $\mathrm{P}$ was measured as previously described.

\section{Results and discussion}

\subsection{Reactor operation I: pre-feasibility studies without biofilm}

\subsubsection{Effect of $\mathrm{pH}$ on phosphorus removal by $\mathrm{HPN}-\mathrm{Pr}$}

The influence of $\mathrm{pH}$ on the $\mathrm{P}$ removal capacity of HPN-Pr is depicted in Figure 2. The experimental results indicated that the $\mathrm{P}$ removal by HPN-Pr decreased slightly when $\mathrm{pH}$ increased, reaching $12 \pm 1 \mu \mathrm{gP} / \mathrm{g}$ at $\mathrm{pH} 5.0,11 \pm 2 \mu \mathrm{gP} / \mathrm{g}$ at $\mathrm{pH} 6.0,9.1 \pm 0.2 \mu \mathrm{gP} / \mathrm{g}$ at $\mathrm{pH} 7.0$ and $8.30 \pm 0.06 \mu \mathrm{gP} / \mathrm{g}$ at $\mathrm{pH}$ 8.0. This can be explained by the superficial charge, according to published results HPN-Pr has zero point charge around $\mathrm{pH}$ 7.5.[18] Therefore, at higher $\mathrm{pH}, \mathrm{HPN}-\mathrm{Pr}$ presents a negative surface charge and repulses the phosphates anions $\left(\mathrm{H}_{2} \mathrm{PO}_{4}^{-}, \mathrm{HPO}_{4}^{2-}, \mathrm{PO}_{4}^{3-}\right)$.[25] Thus, $\mathrm{pH}$ values below the $\mathrm{pH}_{Z P C}$ are more favourable to $\mathrm{P}$ removal performance, because the HPN-Pr surface is positively charged and attracts phosphates anions.

\subsubsection{Polyphosphate removal by $\mathrm{HPN}-\mathrm{Pr}$ at $\mathrm{pH} 6$}

The HPN-Pr performance in eliminating polyphosphate is depicted in Figure 3 . The polyphosphate removal capacity was $12.7 \pm 0.6 \mu \mathrm{gP} / \mathrm{g}$ and is strongly related to the $\mathrm{Al}^{3+}$ content of the HPN-Pr $(1.4 \%)$ and specific mass transfer area. An adsorption capacity of $520 \pm 10 \mu \mathrm{gP} / \mathrm{g}$ was obtained in a previous study in which the $\mathrm{Al}^{3+}$ concentration was $3.3 \%$ and the particle size was much lower, at $0.2 \mathrm{~mm}$.[26] Moreover, Razali et al. obtained a very high capacity of $23.5 \mathrm{mg} \mathrm{P} / \mathrm{g}$ using a by-product with $46 \% \mathrm{Al}_{2} \mathrm{O}_{3}$ and $51 \% \mathrm{Al}^{3+}$ concentration.[27] 


\subsection{Reactor operation II: start-up operation with biofilm growth}

\subsubsection{Phosphorous removal test}

Cávado river water was used to determine the bioreactor P-adsorption capacity with real water. The experimental results for TP and SRP are depicted in Figures 4 and 5.

TP removal was 1.04 and $0.98 \mathrm{mg} \mathrm{P} / \mathrm{g}$ in system 1 and 2, respectively. Therefore, the results show that HPN-Pr is unable to remove all P species (Figure 3), because these can come out in organic particles and increase the TP concentration after digestion. However, regarding SRP in

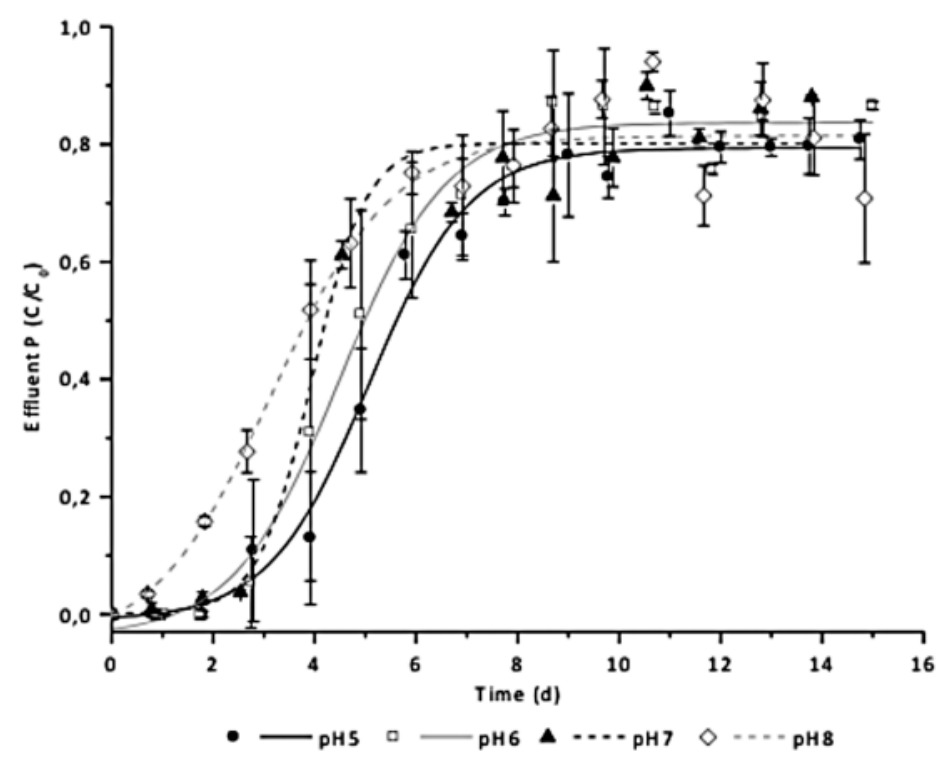

Figure 2. Phosphate removal capacity of HPN-Pr at $\mathrm{pH} 5,6,7$ and 8.

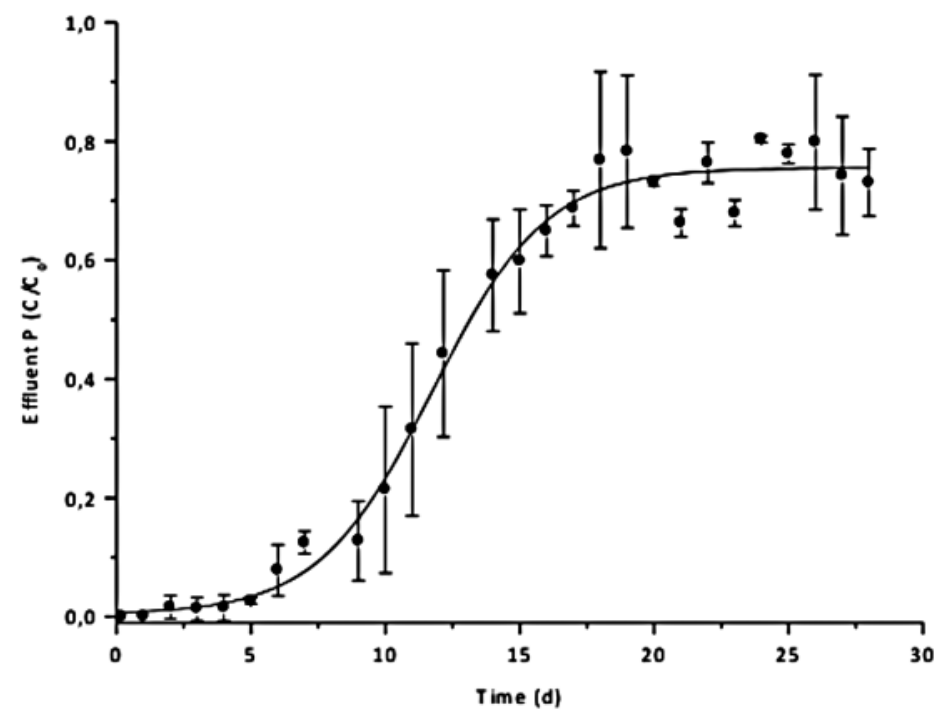

Figure 3. Removal kinetic of polyphosphate by HPN-Pr at pH 6 with an initial [P] of $100 \mu \mathrm{g} / \mathrm{L}$. 


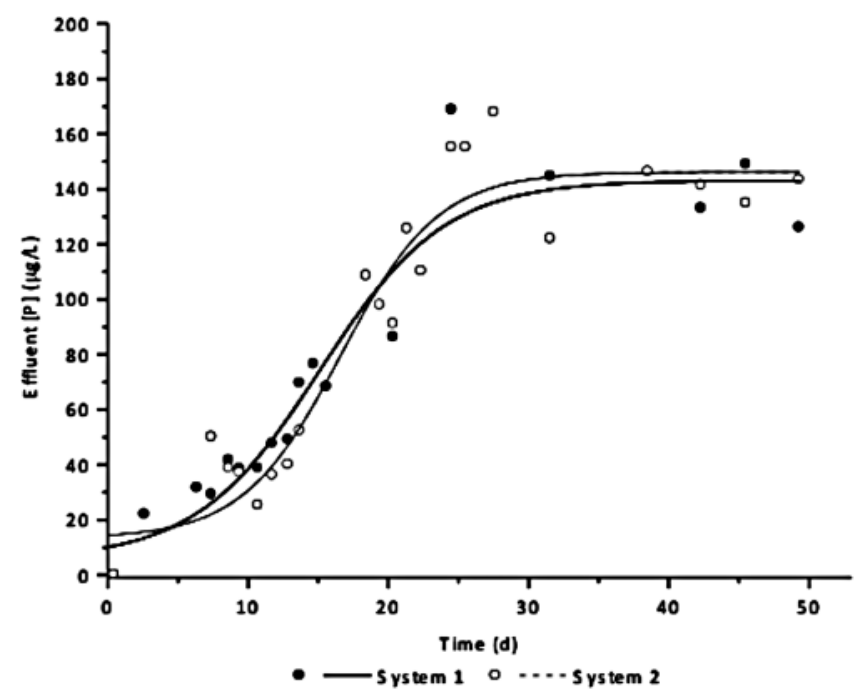

Figure 4. Profile concentration of total phosphate at the outlet of both systems over 50 days at an inlet [SRP] of $266 \mu \mathrm{g} / \mathrm{L}$.

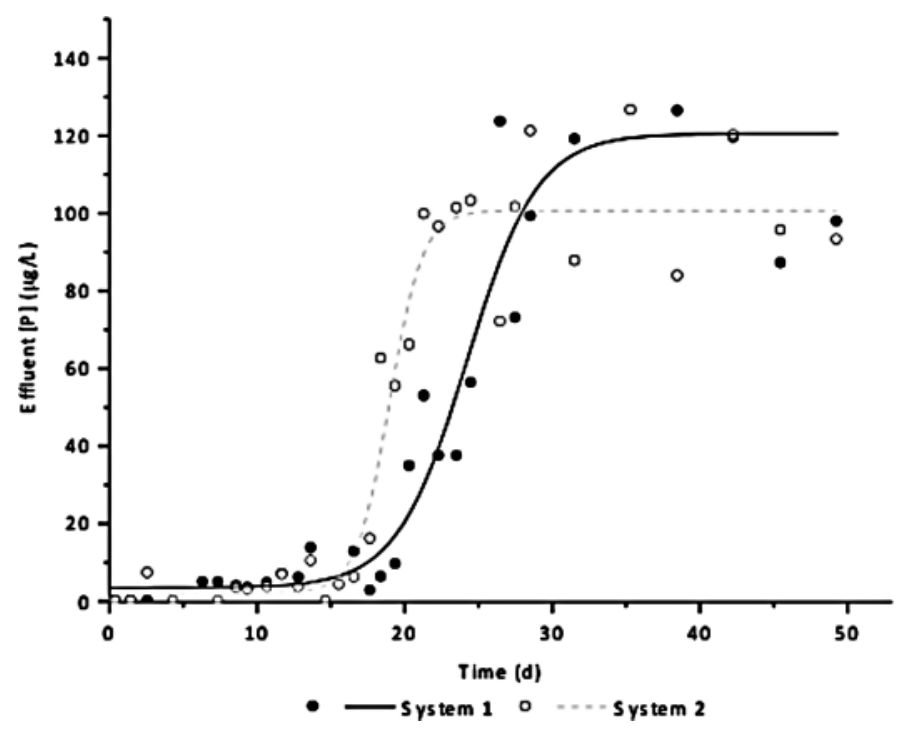

Figure 5. Reactive $\mathrm{P}$ concentration of phosphate at the outlet of both systems over 50 days.

Figure 5, HPN-Pr removal reached $100 \%$ during the first 12 days of operation. The amount of SRP removed was 1.36 and $1.04 \mathrm{mg} \mathrm{P} / \mathrm{g}$ for systems 1 and 2, respectively. Although the concentration of $\mathrm{P}$ at the outlet of both systems stabilised after 50 days of operation, the reactor was not saturated and maintained a removal capacity of $55 \%$ for system 1 and $62 \%$ for system 2 . This pattern might be explained by multilayer adsorption of $\mathrm{P}$ on HPN-Pr, as suggested by the adsorption isotherm and bioconsumption kinetics.[18,28]

Other published studies indicate that $\mathrm{P}$ removal depends on the type of adsorbent. Razali et al. removed $50.7 \mathrm{mg} \mathrm{P} / \mathrm{g}$ using aluminium sludge from a water treatment coagulation process.[27] Kabayama et al. removed $11.3 \mathrm{mg} \mathrm{P} / \mathrm{g}$ from a $1 \mathrm{mM}$ disodium hydrogen phosphate aqueous solution passing through the column containing aluminium oxide hydroxide.[29] Drizo et al. 


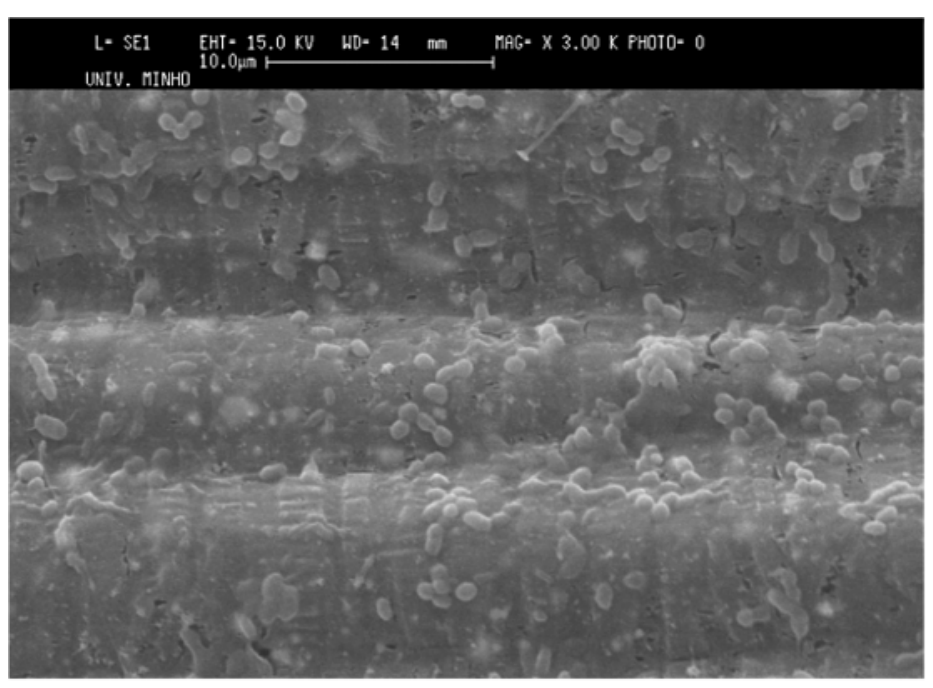

Figure 6. SEM of the HPN-Pr surface with biofilm.

assessed P removal by shale and bauxite clays and obtained 0.73 and $0.35 \mathrm{mg} \mathrm{P} / \mathrm{g}$, respectively.[30] Aluminium wastes from a water treatment plant adsorbed 0.48 and $0.14 \mathrm{mg} \mathrm{P} / \mathrm{g}$, when used in aquaculture wastewater treatment.[31]

\subsubsection{Biofilm assessment}

As the bioreactor runs, a biofilm begins to form on HPN-Pr particles due to its rough surface. Figure 6 clearly shows ellipsoid bacteria similar to beans on the HPN-Pr surface. The biofilm becomes visible at the end of the second week when a change in particle colour from white to yellowish was noticed.

The DGGE band-pattern of the biofilm formed on HPN-Pr indicated the presence of several ribotypes, which reveals a high microbial diversity. This is in accordance with other studies that found similar microbial diversity in natural aquatic ecosystems.[32,33] Scanning electrom micrographs from the HPN-Pr surface confirm the presence of a well-established microorganism community (Figure 6).

The biofilm formed after 50 days was quantified as TS at three different columns heights, Figures $7 \mathrm{a}$ and $\mathrm{b}$. The data indicate that the biofilm concentration was proportional to bulk liquid carbon and macro-nutrients. However, the higher concentration of biofilm at the bottom of column 2 was due to the biofilm formed inside the pipe that connected the columns.

\subsubsection{Phosphorus removal by adsorption on HPN-Pr particles and biofilm metabolism}

The amount of P present in the biofilm and HPN-Pr particles was assessed as indicated in the Methods. To measure a concentration profile, samples were taken at three distinct points for each system (Figure 1). The desorption experiment quantified the P adsorbed by HPN-Pr particle surface and by the biofilm due to biosorption. The results indicated that both the biofilm and the polymeric material contributed to P removal. Moreover, the biofilm formed on HPN-Pr particles enhanced the removal performance. As seen in Figure 8, the highest amount of $\mathrm{P}$ was consumed at the bottom of the columns and this decreased along its length. These results are in agreement with the presence of a biofilm concentration profile along the reactor. 


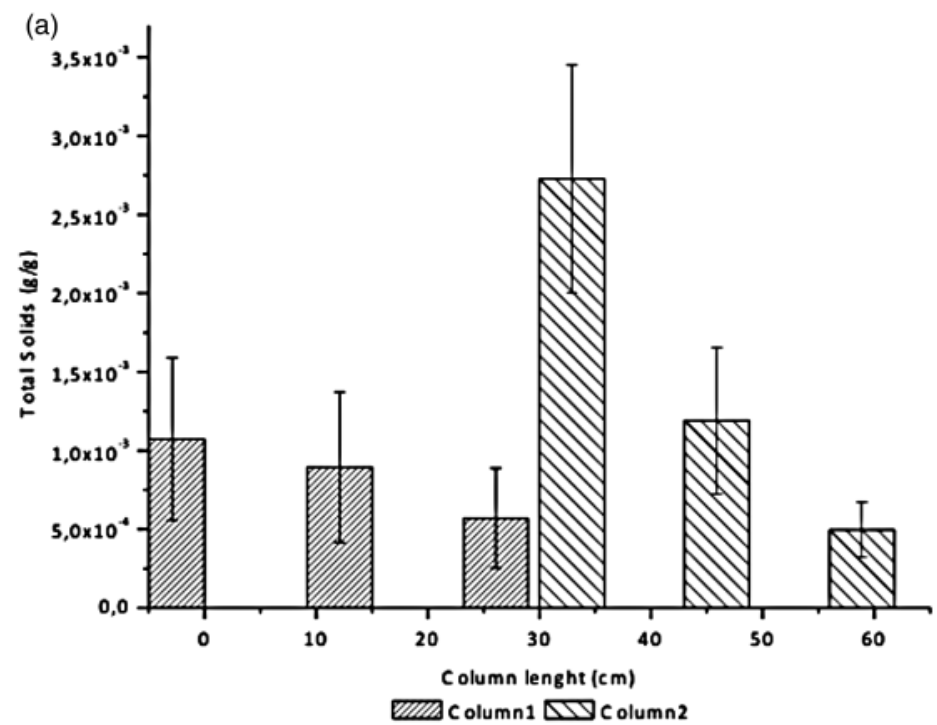

(b)

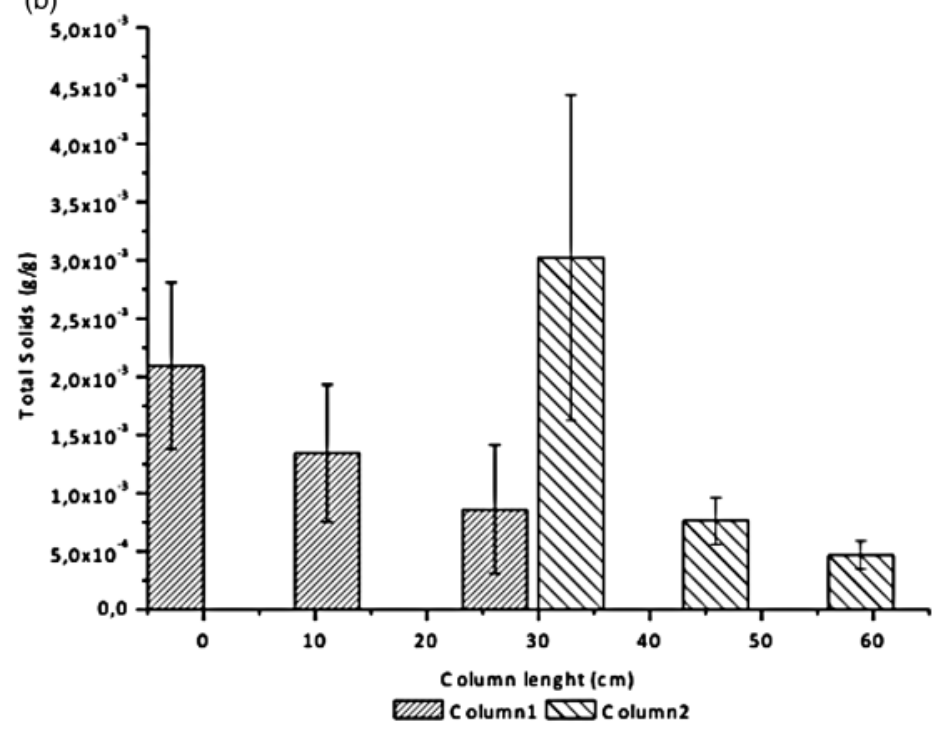

Figure 7. Biofilm total solids distribution: (a) system 1; (b) system 2.

\subsection{Mathematical modelling of $P$ removal}

The mathematical modelling was assessed using the Freundlich and Monod equations ( 3 and 4) and data from Tables 2 and 3:

$$
\begin{array}{r}
S=0.76 \times C^{0.56} . \\
R=\frac{0.12 \times C}{55+C} .
\end{array}
$$

$\mathrm{P}$ adsorption on HPN-Pr is much faster than biofilm formation. Biofilm growth is limited by $\mathrm{P}$ availability until HPN-Pr reaches saturation (Figure 9, $t=400 \mathrm{~h}$ ). After this point, the $\mathrm{P}$ concentration in the bulk liquid triggers biofilm growth until it reaches the equilibrium (Figure 9, 


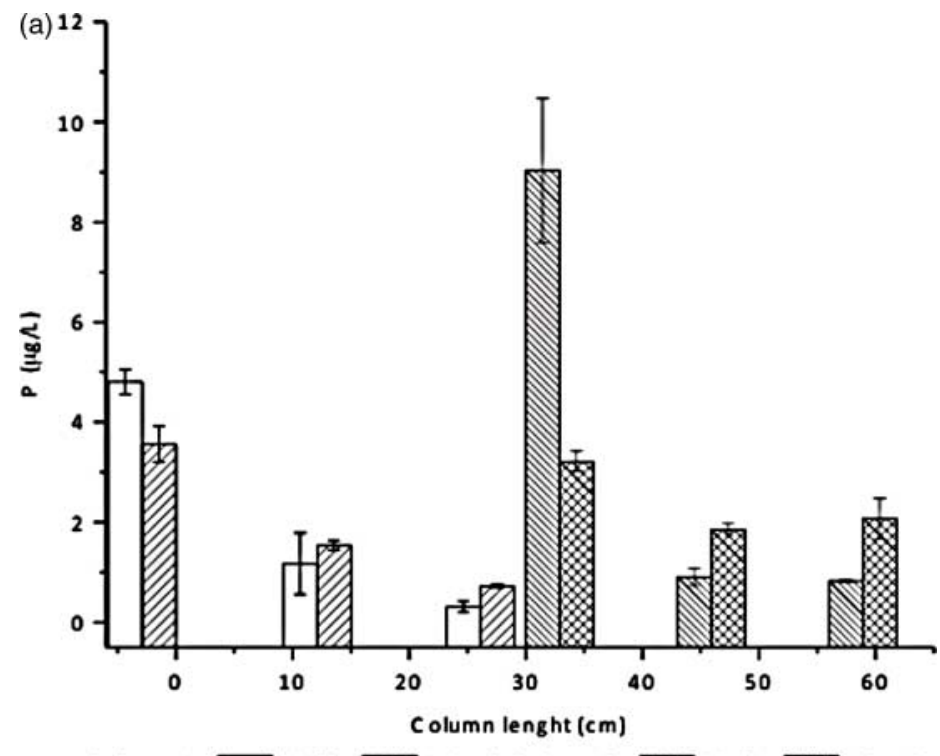

Column $1-\square$ B iofilm $\square$ Ads orb Column 2 - $\square$ B iofilm $\square$ Ads orb

(b)

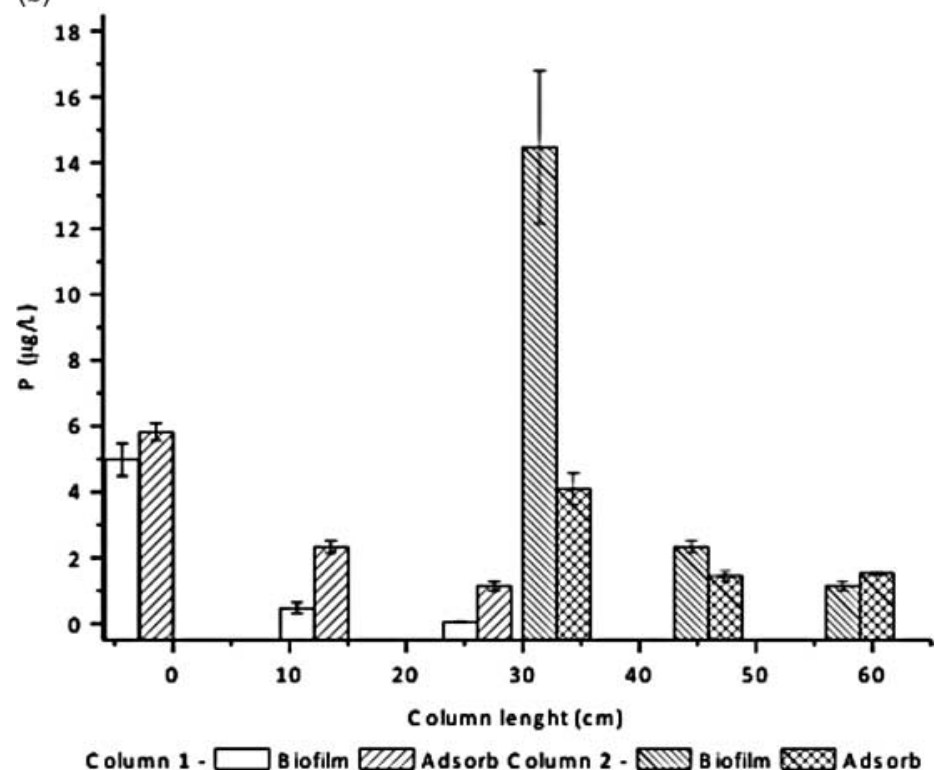

Figure 8. Distribution of the amount of phosphate in the biofilm and adsorbed to the HPN-Pr particles: (a) system 1; (b) system 2 .

$t=1200 \mathrm{~h}$ ). To compare the effects of $\mathrm{P}$ removal by adsorption and biomass growth, this process was inactivated in the model, allowing $\mathrm{P}$ removal to occur only by adsorption. The results are presented in Figure 9 (solid line).

It is possible to detect that, if $\mathrm{P}$ removal by biofilm does not occur, the concentration of reactive $P$ will increase and reach saturation earlier (comparing dashed and solid lines in Figure 9). When HPN-Pr is fully saturated, the P concentration at inlet $(250 \mu \mathrm{g} / \mathrm{L}$ of $\mathrm{P})$ is the same as at the outlet (Figure 9, $t=1200 \mathrm{~h}$ ), showing that this process could not remove more P. Thus, adsorption process is more important over a short-time perspective (until saturation), whereas biofilm growth 


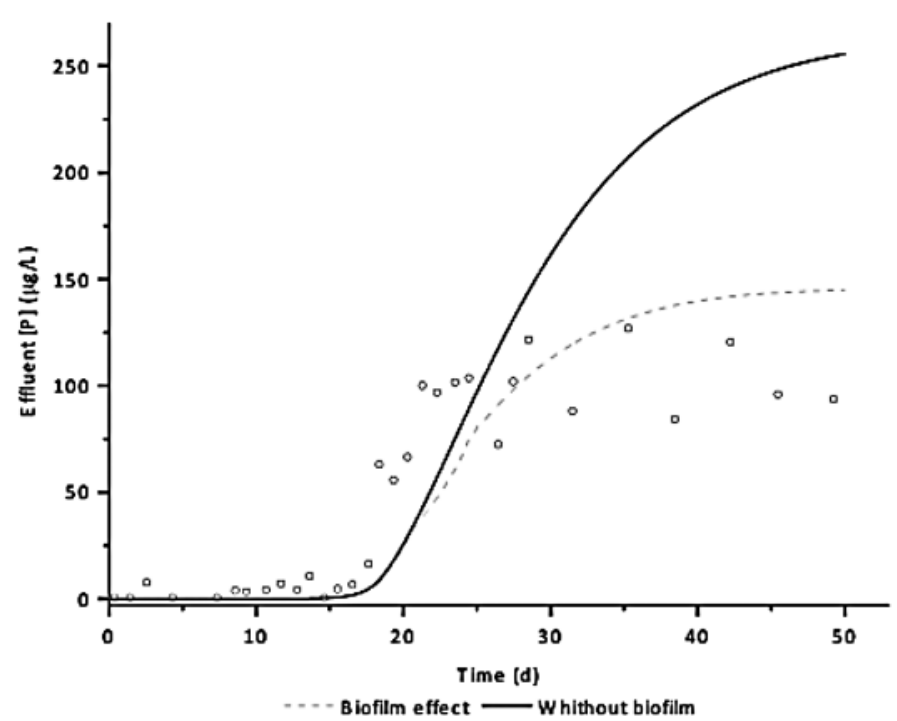

Figure 9. Predicted average values for phosphate removal by HPN-Pr in the presence and absence of biofilm obtained using AQUASIM model.

has advantages over the long-term. However, one can anticipate that biofilm growth will reach a limit and biomass will tend to wash-out. In that case, reactive $\mathrm{P}$ will continue to be removed, but the organic $\mathrm{P}$ concentration may increase at the reactor outlet. Therefore, in order to prevent excessive biomass growth in the reactor, adsorption/regeneration cycles of HPN-Pr could be made for semi-continuous $\mathrm{P}$ removal and to recover the $\mathrm{P}$ that has been adsorbed. A future $\mathrm{P}$ removal application in wastewater treatment may be foreseen based in this hybrid technology.

\section{Conclusions}

The hybrid polymer nanocomposite biofilm reactor is a novel and promising integrated technology combining chemical adsorption and biological processes to eliminate $\mathrm{P}$ from natural waters. Removal performances of $1.20 \mathrm{mg} \mathrm{P} / \mathrm{g}$ of SRP and $1.01 \mathrm{mg} \mathrm{P} / \mathrm{g}$ of TP were obtained, reaching a saturation of around $50 \%$. Moreover, this material allows $\mathrm{P}$ recovery and can be used several times, preserving the same efficiency.

A mathematical adsorption-biosorption model was applied to predict reactor performance. The model indicated that the biological activity has a positive effect on reactor performance, increasing the amount of SRP removed.

\section{Acknowledgements}

The authors acknowledge the Portuguese Foundation for Science and Technology for the financial support under Project SFRH/BD/39085/2007.

\section{References}

[1] Smith VH, Tilman GD, Nekola JC. Eutrophication: impacts of excess nutrient inputs on freshwater, marine and terrestrial ecosystems. Environ Pollu. 1999;100(1-3):179-196.

[2] Correll DL. Phosphorus: a rate limiting nutrient in surface waters. Poultry Sci. 1999;78(5):674-682. 
[3] Morse GK, Brett SW, Guy JA, Lester JN. Review: phosphorus removal and recovery technologies. Sci Total Environ. 1998;212(1):69-81.

[4] Nyenje PM, Foppen JW, Uhlenbrook S, Kulabako R, Muwanga A. Eutrophication and nutrient release in urban areas of sub-Saharan Africa - A review. Sci Total Environ. 2010;408(3):447-455.

[5] Martins G, Ribeiro D, Pacheco D, Cruz JV, Cunha R, Gonçalves V, Nogueira R, Brito AG. Prospective scenarios for water quality and ecological status in Lake Sete Cidades (Portugal): the integration of mathematical modelling in decision processes. Appl Geochem. 2008;23(8):2171-2181.

[6] Ribeiro D, Martins G, Nogueira R, Cruz JV, Brito AG. Phosphorus fractionation in lake volcanic sediments (Azores - Portugal). Chemosphere. 2008;70(7):1256-1263.

[7] Hongshan L, Songqiang L. Biochemical Mechanism of the eutrophication and its prevention - the deep treatment of wastewater and its denitrification and dephosphorization. Maritime Sci Bulletin. 2003;5:32-39.

[8] Hupfer M, Rübe B, Schmieder P. Origin and diagenesis of polyphosphate in lake sediments: a 31P-NMR study. Limnol Oceanogr. 2004;49(1):1-10.

[9] de-Bashan, L.E. Bashan, Y. Recent advances in removing phosphorus from wastewater and its future use as fertilizer (1997-2003). Water Research. 2004;38(19):4222-4246.

[10] Yuan G, Wu L. Allophane nanoclay for the removal of phosphorus in water and wastewater. Sci Technol Adv Mat. 2007;8(1-2):60-62.

[11] Hano T, Takanashi H, Hirata M, Urano K, Eto S. Removal of phosphorus from wastewater by activated alumina adsorbent. Water Sci Technol. 1997;35(7):39-46.

[12] Donnert D, Salecker M. Elimination of phosphorus from municipal and industrial waste water. Water Sci Technol. 1999;40(4-5):195-202.

[13] Miller, N. Locally available adsorbing materials, sediment sealing and flocculants for chemical remediation of lake and stream. Analytical \& Environmental Consultants. Report prepared for Environment Bay of Plenty. Rotorua, New Zealand; 2005.

[14] Zeng L, Li X, Liu J. Adsorptive removal of phosphate from aqueous solutions using iron oxide tailings. Water Res. 2004;38(5):1318-1326.

[15] Zhang G, Liu H, Liu R, Qu J. Removal of phosphate from water by a Fe-Mn binary oxide adsorbent. J Colloid Interf Sci. 2009;335(2):168-174.

[16] Cordell D, Drangert J, White S. The story of phosphorus: global food security and food for thought. Global Environ Change. 2009;19(2):292-305.

[17] Ashley K, Cordell D, Mavinic D. A brief history of phosphorus: from the philosopher's stone to nutrient recovery and reuse. Chemosphere. 2011;84(6):737-746.

[18] Heffer, P., Prud'homme, M. Medium-term outlook for global fertilizer demand, Supply and Trade 2008-2012. 76 ${ }^{\text {th }}$ IFA Annual Conference; 2008 May 19-21; Vienna, Austria.

[19] Oliveira M, Machado AV, Nogueira R. Phosphorus removal from eutrophic waters with an aluminium hybrid nanocomposite. Water, Air \& Soil Pollu. 2012;223(8):4831-4840.

[20] Slater FR, Johnson CR, Blackall LL, Beiko RG, Bond PL. Monitoring associations between clade-level variation, overall community structure and ecosystem function in enhanced biological phosphorus removal (EBPR) systems using terminal-restriction fragment length polymorphism (T-RFLP). Water Res. 2010;44(17):4908-4923.

[21] Oliveira M, Nogueira R, Machado AV. Synthesis of aluminium nanoparticles in a PP matrix during the melt: effect of the alkoxide organic chain. React Functi Poly. 2012;72:703-712.

[22] Oliveira M, Nogueira R, Machado AV. Hybrid nanocomposite preparation in a batch mixer and a twin-screw extruder. Adv Poly Tech. 2012; 32(S1):E732-E740.

[23] Eaton AD, Clesceri LS, Greenberg AE. Standard methods for the examination of water and wastewater. 19th ed. Washington DC: American Public Health Association; 1995. p. 4-153-4-155.

[24] Reichert P. AQUASIM - a tool for simulation and data analysis of aquatic systems. Water Sci Technol. 1994;30(2):2130.

[25] Xiong J, He Z, Mahmood Q, Liu D, Yang X, Islam E. Phosphate removal from solution using steel slag through magnetic separation. J Hazard Mater. 2007;152(1):211-215.

[26] Schröder JJ, Cordell D, Smit AL, Rosemarin a sustainable use of phosphorus (report). 2009; EU Tender ENV.B.1/ETU/2009/0025: 1-71.

[27] Razali M, Zhao YQ, Bruen M. Effectiveness of a drinking-water treatment sludge in removing different phosphorus species from aqueous solution. Separa Purifi Technol. 2007;55(3):300-306.

[28] Benyoucef S, Amrani M. Adsorption of phosphate ions onto low cost Aleppo pine adsorbent. Desalination. 2011;271(1-3):231-236.

[29] Kabayama M, Sakiyama T, Kawasaki N, Nakamura T, Araki M, Tanada S. Characteristics of phosphate ion adsorption-desorption onto aluminium oxide hydroxide for preventing eutrophication. J Chem Eng Japan. 2003;36(4):499-505.

[30] Drizo A, Frost CA, Grace J, Smith KA. Physical-chemical screening of phosphate removing substrates for use in constructed wetland systems. Water Res. 1999;33(17):3595-3602.

[31] Mortula MM, Gagnon GA. Alum residuals as a low technology for phosphorus removal from aquaculture processing water. Aquacult Eng. 2007;36(3):233-238.

[32] Newton RJ, Jones SE, Eiler A, McMahon KD, Bertilsson S. A guide to the natural history of freshwater lake bacteria. Microb Molec Biology Rev. 2011;75(1):14-49.

[33] Besemer K, Singer G, Limberger R, Chlup AK, Hochedlinger G, Hödl I. Biophysical controls on community succession in stream biofilms. Applied Environ Microb. 2007;73(15):4966-4974. 